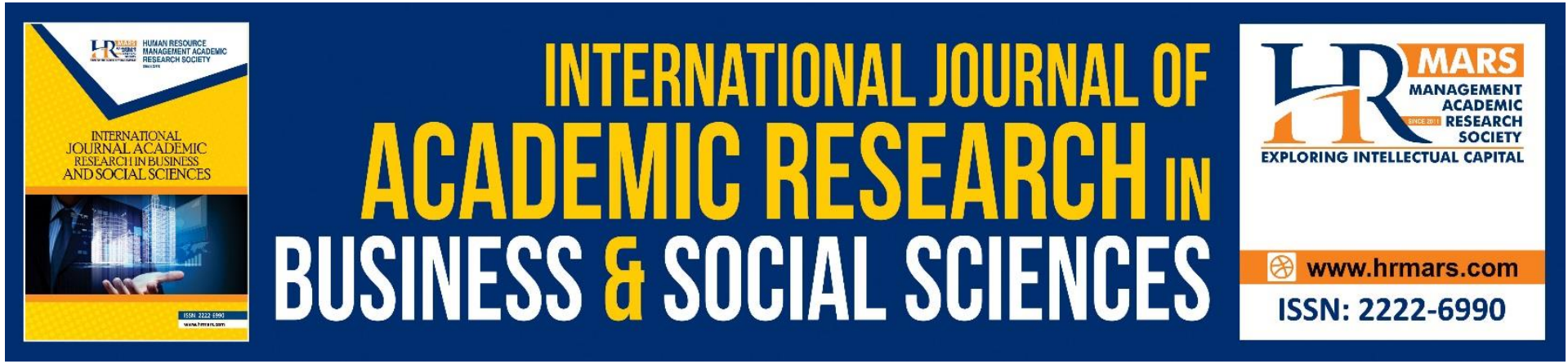

\title{
Discourse in Animation of Kingfisher Stories Wood that Changes Places and Palm Tree
}

Siti Nursyakirah Saharudin, Normaliza Abd Rahim, Nik Rafidah Nik Muhamad Affendi, Roslina Abu Bakar

To Link this Article: http://dx.doi.org/10.6007/IJARBSS/v11-i7/9917

DOI:10.6007/IJARBSS/v11-i7/9917

Received: 11 May 2021, Revised: 15 June 2021, Accepted: 27 June 2021

Published Online: 08 July 2021

In-Text Citation: (Saharudin et al., 2021)

To Cite this Article: Saharudin, S. N., Rahim, N. A., Affendi, N. R. N. M., \& Bakar, R. A. (2021). Discourse in Animation of Kingfisher Stories Wood that Changes Places and Palm Tree. International Journal of Academic Research in Business and Social Sciences, 11(7), 208-219.

Copyright: @ 2021 The Author(s)

Published by Human Resource Management Academic Research Society (www.hrmars.com)

This article is published under the Creative Commons Attribution (CC BY 4.0) license. Anyone may reproduce, distribute, translate and create derivative works of this article (for both commercial and non-commercial purposes), subject to full attribution to the original publication and authors. The full terms of this license may be seen at: http://creativecommons.org/licences/by/4.0/legalcode

Vol. 11, No. 7, 2021, Pg. 208 - 219

Full Terms \& Conditions of access and use can be found at http://hrmars.com/index.php/pages/detail/publication-ethics 


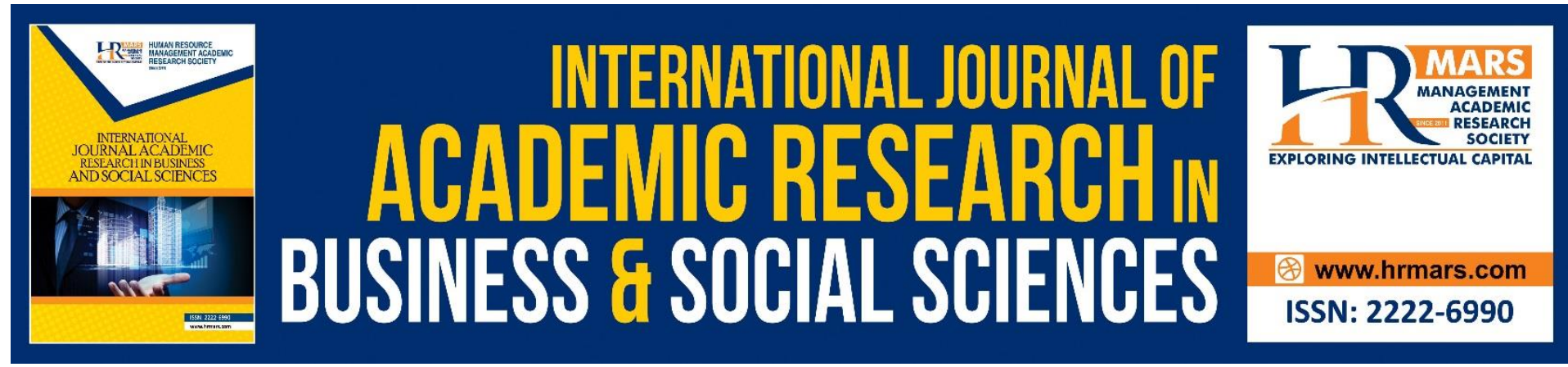

\title{
Discourse in Animation of Kingfisher Stories Wood that Changes Places and Palm Tree
}

\author{
Siti Nursyakirah Saharudin \\ Faculty of Modern Language and Communication, University Putra Malaysia, Serdang, 43400 \\ Selangor, Malaysia \\ Email: syakirah.shrudin@gmail.com
}

\section{Normaliza Abd Rahim, Nik Rafidah Nik Muhamad Affendi, Roslina Abu Bakar \\ Malay Language Department, Faculty of Modern Language and Communication, University \\ Putra Malaysia, Serdang, 43400 Selangor, Malaysia \\ Email: nliza@upm.edu.my,nrafidah@upm.edu.my, lynabubakar@upm.edu.my}

\begin{abstract}
This study is based on observations scientific studies which on explain the study of folklore through animation Kingfisher Stories published by Dewan Bahasa dan Pustaka (DBP). There has been no comprehensive study of animated folklore. Based on the above statement, this study intends to fill the space by examining the animated folklore published by DBP. This study outlines two main objectives, namely to identify and discuss the folklore script discourse of hypothetical elements. This study uses library methods and data analysis. This study applies by using discourse theory by Normaliza Abd Rahim (2019) which emphasizes the third element which is the element of assumptions in analyzing the animated folklore of Wood That Changes Places and Palm Tree. In addition, this study will interview several primary school students and documented in written form for the purpose of data analysis. The findings of this study successfully apply the values of folklore among the community, especially primary school students. In conclusion, the animation of the Kingfisher Stories folklore can be accepted by the community now even though it has been adapted in various forms of animation. It is hoped that future studies can focus on this folklore especially in the form of animation.
\end{abstract}

Keyword: Animation, Folklore, Discourse, Kingfisher Stories, Animation Discourse

\section{Introduction}

The first animation in Malaysia began in 1956 with the creation of the national film logo, the tiger finder logo. The purpose of this production was for the first free film screenings in the villages for the government campaign in conjunction with the elections. Following that, Malaysian animation continued to grow around the 1990s. In 1994 it has grown rapidly, GilaGila magazine ads using animated characters from the magazines have been produced with the aim of promoting Gila-Gila magazine. Usually animation or even as a cartoon is so popular 
with children because the character of each cartoon character created by the animator is enough to entertain the audience and attract public attention. The development of national animation is seen to be growing and interesting with this compilation animation technology (Mohammed, 2015). The first short animated film was Hikayat Sang Kancil and aired in 1983. The short animated films between 1984 and 1987 were The Deer and the Monkey, The Deer and the Crocodile, The Wise Crow, The Proud Rabbit and The Great Lion (Mohammed, 2015). Malay folklore a story that comes from the community and develop in society in the past. In addition, the Malay folklore into the unique characteristics of each nation culturally diverse, inclusive culture and history. At the time, the stories people tell about Malay acquire a culture of the nation itself. This study was conducted is an observation based on folk animated stories that use the animated stories of the people of Kingfisher Stories. Behind the follow -up, there is a hidden question about the animated script of the Kingfisher Stories folklore discourse against primary school students. Studies on folklore animation that are only influenced and influenced by animation abroad (Muhamad, Yusmilayati \& Mohd, 2019). This situation occurs due to the relationship between the making of other films and the writing of the animated script that was studied needs to be detailed by using discourse analysis through the animation of Kingfisher Stories folklore. It also appears as if our country is short of animated films of folklore and capable relationships. Previous studies on matters such as the study of Normaliza (2018) who examined texts and writings on folklore, verses, poems, lyrics and others. Therefore, a study on folklore animation in Malaysia needs to be done. With the problem statement, this study shows the animated script of the storytelling Pekaka folklore. Therefore, this study will identify and discuss the discourse of folklore scripts as well as use the discourse analysis of danaian elements that show views on folklore.

\section{Literature Review}

A study on animation conducted by Noor, Eizah \& Ahmad (2019). This study also discusses civility in communication through the children's animated films, namely stereoscopic 3D animated film first Malay language in Malaysia. This study also uses the film corpus that is the animated film Bola Kampong The Movie (2013), the study data is transcribed in written form, sorted and described based on the approach that has been stated. The results of this study found that basic decency and constraint decency are based on the context of use. The results of a study by Noor, Eizah \& Ahmad (2019) are in line with the results of a study by Siti (2018) where the aspect of politeness in the animated film Geng Upin and Ipin: Gang Adventure Begins which focuses on the greeting system. The animation of this film has proved that this film has aspects of decency and noble values that are successfully inculcated through animated films.

Crosthwait (2020) conducted a study on film animation. The animation of the film studied is from the animation of the Disney-Pixar film entitled Coco. The results of the study found that text comparisons showed encounters with death could be linked to openness to the transition of circumstances that led the audience to another dimension. However, the approach applied in this study combines musical and animated aesthetics to direct the audience into their own animated space to enhance emotion and transition. It is appropriate that this animation can be disseminated in animation in Malaysia so that the display of storytelling brought by the author can be felt by the audience. This is because, with the animation of this story, people can feel and apply the elements that have been felt into their daily lives. The results of the Crosthwait (2020) study are almost the same as the study by Muhamad, Yusmilayati \& Mohd (2019) stated that the concept of Malay identity in the local animation story can contribute 
to the animation which can also be followed by various segments of society. Justerus study Muhamad, Yusmilayati \& Mohd (2019) focus on knowledge, awareness and practice of Malay identity by using the characteristics of Malay identity that saw aspects of speech, daily practice and area of residence. Results of the study by Muhamad, Yusmilayati \& Mohd (2019) showed that all three of these features are closely interlinked with each other to form an animated story Malay identity.

A study of animation by Golding (2019). The study also argues that this animated series uses magical realism to illustrate animated capitalism in order to animate characters. Nickelodeon's animated series Rocko's Modern Life suggested by the theories of Guy Debord and Imamura Taihei. The results of the study found that animated stories have a competition between capitalist animism and native animism in animation. This is because, with the presence of characters like this, the animated story becomes interesting as well as gaining an idea of the author's ideas to the community. The results of Golding's (2019) study are in line with the results of a study by Herhuth (2017) where the continuity of social implications and historical desire to animate characters in animated stories. Herhuth's (2017) study found that the relationship between animism, animation and colonialism with the relationship between colonizers and colonizers suggests that animation is considered in terms of anthodology. The depiction of animism in the animation of Rocko's Modern Life requires more and more scholars to study how animism is interpreted and compared in a variety of animated works. Furthermore, a study by Roslina (2020) said that the Malay folklore and its delivery is one of the typical Malay heritage. Review by Roslina (2020) also focuses on the uniqueness of the language used in the delivery of Malay folklore and poetry using hyperbole to balance and enhance the effect of telling the story. The results show that the nature of the storytelling is presented in the form of animation through traditional media and technology. The study by Roslina (2020) is almost in line with the study by Faryna \& Normah (2017) also stated that apart from the storyline, character design is also the backbone in animation. Accordingly, the study by Nik, Awang \& Normaliza (2019) stated that the discovery of a special collection of children's stories in Malay at the University of Leiden, Netherlands show the community traditionally keep reading materials appropriate for use of children there. A study by Nik, Awang Azma \& Normaliza (2019) also focuses on three stories in the story of children 26 May Collection 1862 which have no specific title, only known as story 1, story 2 and story story 3 and 2 are contained in a collection of parable stories that are difficult for the younger generation to recognize. The results show that there are folklore that have a certain function in benefiting children as well as less exposed to the stories of their ancestral heritage. Review by Nik, Awang \& Normaliza (2019) in line with the study conducted by Normaliza, Awang \& Nik (2018) on the folklore of the Malay where 16 value recommended by the National Philosophy of Education was used and this study also selected ten folklore animations from Storytelling Deaf.

As an extension of the study of animation from the study of animation Isojärvi (2019) who stated that the film animation of the father character in each film has a different tone of presentation. This study by Isojärvi (2019) focuses on the elements of fatherhood introduced and the characteristics of the transition of paternal sentiment in Walt Disney's animated films: Pinocchio, Dumbo and Bambi. The results of Isojärvi's (2019) study show that the construction of film animation through the father role character influences the reality of past lives. However, the study by Isojärvi (2019) was found to be in line with the study by Glassmeyer (2017). Glassmeyer's (2017) study states that important characters in classical times were not innocent and naive children, but rather disturbing American mentors. In this case clearly, the 
animated film depicts a father figure who can be emulated against the character borne as a father who is responsible in supporting the family. In addition, this father character is socially required of achievement through the success shown by their child. Moreover, the traits of the father's character are not lost in the slightest over his resources despite being squeezed in adversity. Thus, the study of Isojärvi (2019) and Glassmeyer (2017) says that the father character in these animated films can contribute to the success of the storytelling that the writer wants to convey to the society.

Thus, this study would like to identify and discuss the hypothetical discourse of Kingfisher Stories folklore animation.

\section{Metodology}

This section will touch on the methods used to make this study a success. This study refers to two series of Kingfisher Stories folklore animation, namely the Wood That Changes Place and Palm Tree folklore animation written by Normaliza (2018). This animated series of Kingfisher Stories folk tales is published by Dewan Bahasa dan Pustaka through the 'Google Play Store' storage on smartphones. The Kingfisher Stories folklore animated series has 33 folklore animated series. However, this study only focuses on two animated series of folklore only, namely Wood That Changes Place and Palm Tree. Researchers use the theory of discourse analysis by Normaliza (2019) which contains three elements namely content, context and assumptions. The assumption element is divided into three aspects, namely opinion, reference and question. The opinion aspect is about the view of something that is said by a person. In this part of the opinion can usually arise new ideas, solutions to problems and so on. Next, the aspect of reference is more descriptive about something to be said. Therefore, this reference can be either a reference to something that is around the individual or something that is far from the view that leads to something that other individuals have experienced in the event. Whereas, aspects are questions involving important discussions such as meetings, decision -making discussions and so on. The question, on the other hand, requires an answer from what is being asked. Therefore, this question is asked for the reason of requiring the listener's attention to what is being discussed and requiring understanding in the topic being discussed.

\section{Synopsis of the Animated Series Wood That Changes Place}

In ancient times, there were many wooden trees growing on the hills. They lived very happily. The hill tells that the trees growing above him are gripping into his body. Therefore the trees will be able to source the minerals available on the hills. One day, the hill instructed the other tree friends about the time when humans would come to him to take the gold that was in the hill. However, the trees were not up to the heart to leave the hill. One day, a man came to get the gold contained in the hill. Soon, humans began digging and blowing up hills to find gold. The trees above it were thrown everywhere. Nowadays, living timber trees are everywhere. They are sad for not being together with other friends.

\section{Palm Tree}

In the past, palm trees could speak. Palm trees grow everywhere. The palm tree is happy to be with other friends. Every day the palm trees would chat together. One day, people came near the palm trees. The palm trees sighed and cried as their bodies would be hacked by humans. However, the palm trees could do nothing. One day, the nipah tree was hurt again. 
His body has been mutilated by humans. The palm tree is only able to survive and shed tears. Palm trees are very sad to remember their fate. Every morning, the pruned palm tree would cry involuntarily. They know humans want tears. Humans will wait for the nipah water to be full in the bamboo. All the dreamy palm trees remembered their own fate. The palm tree knows, humans will come every day to get tears. The palm tree looked at the sky and hoped the rain would arrive soon. Palm trees know that every time the rainy season arrives, they will live more fertile. Palm trees smiled at each other. Their lives went on very happily even though they knew, they were watching over humans.

\section{Results and Discussions}

Folklore animation serves as a medium of entertainment animation to stimulate the creativity and thinking of the community. An interesting storyline will produce a literary work that has a specific goal, especially for children. This research highlights the animation of folk tales selected in line with the experiences of the community. The animated story on display contains values that can benefit not only children but all walks of life. This can be seen through the story of Wood That Changes Place and Palm Tree through the Kingfisher Stories folklore series.

\section{Aspects of Opinion in Folklore Animation Wood That Changes Place}

Tablel 1: Opinion based on interview thru Wood That Changes Place

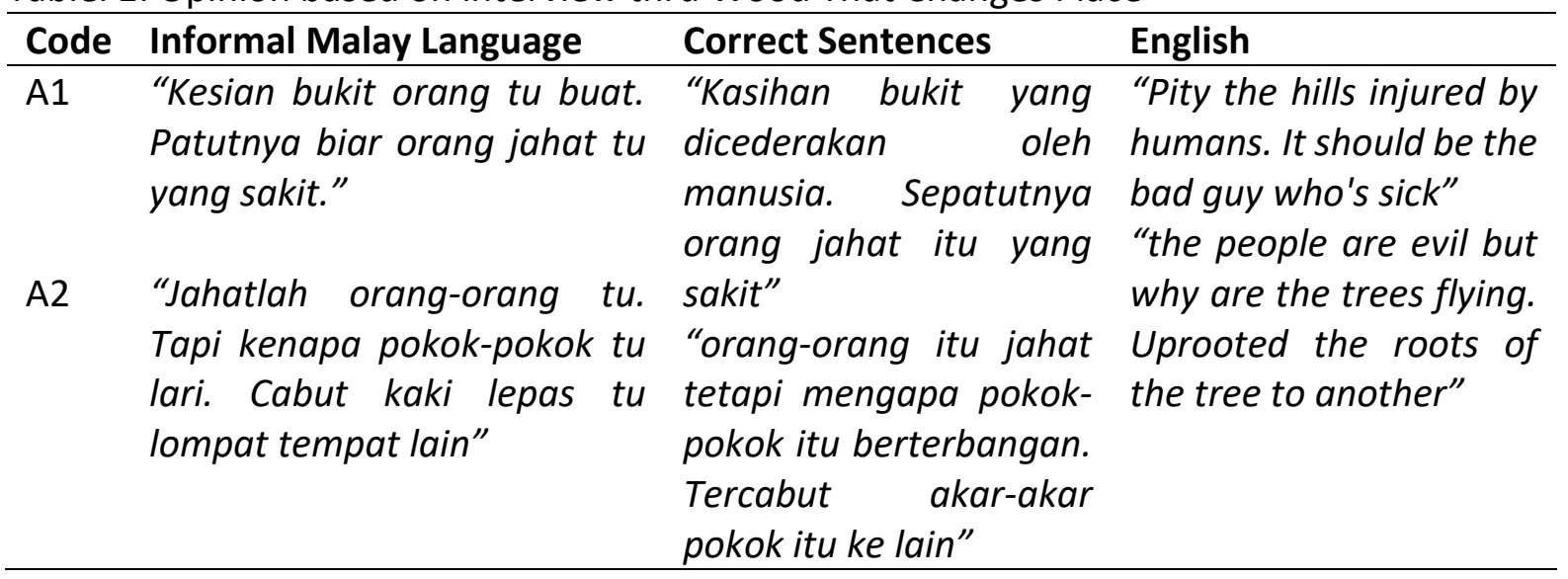

Table 1 above shows the elements of assumptions through the opinion aspects for $A 1$ and $A 2$.

The above conversation shows a different conversation situation. Conversation A1 shows a description of a nine-year-old girl giving an opinion on a storytelling deaf folk tale that is Wood That Moves Places. Subject A1 gave his opinion on a hill that is in pain as a result of human evil deeds that often damage nature. In the animated series watched, hills and other trees live happily on top of the hill. When the greedy man arrived on the hill, then the hill had to be blown up because they wanted to take the gold that was in it. So subject A1 gave his opinion on the act. For example, "Pity the hills injured by humans. It should be the bad guy who's sick", indicating that the opinion described by subject $A 1$ is the action he will take to do to the bad guy who is damaging nature. In this case, it can be described A1 is very sensitive to those around who are in trouble. Furthermore, when one commits evil to another, then it is retaliated with evil. While doing good is rewarded with kindness. The month A2 above shows the opinion given about the animated story that was watched, namely the wood that changed places. The opinions contained in the conversation above show a fantasy -minded A2 who 
assumes the trees found in the animated series have legs. For example, "the people are evil but why are the trees flying. Uprooted the roots of the tree to another", showing that the opinion given by A2 has its own uniqueness. In other words, A2 thinks living trees have legs whereas trees only have roots and have no legs. Thus, the statement in the form of opinion above shows that $A 1$ and $A 2$ have different opinions including their way of thinking, imagination and views on the animation of this folklore.

\section{Palm Tree}

Table 2: Opinion based on interview thru Palm Tree

\begin{tabular}{|c|c|c|c|}
\hline Code & Informal Malay Language & Correct Sentences & English \\
\hline \multirow[t]{4}{*}{$\begin{array}{l}\text { A1 } \\
\text { A2 }\end{array}$} & $\begin{array}{l}\text { "kesiannya asyik kena pukul } \\
\text { je. Kan pokok tu ada tajam. } \\
\text { Pukul orang jahat tu dengan } \\
\text { tajam-tajam" }\end{array}$ & $\begin{array}{l}\text { "Kasihan pokok dipukul } \\
\text { oleh manusia. Pokok itu } \\
\text { mempunyai tajam, } \\
\text { boleh sahaja pokok itu }\end{array}$ & $\begin{array}{l}\text { "Pity the tree was } \\
\text { beaten by humans. The } \\
\text { tree has a sharp, can } \\
\text { only the tree impose a }\end{array}$ \\
\hline & "Pokok tu nangis bila orang tu & $\begin{array}{l}\text { mengenakan duri yang } \\
\text { tajam kepada orang } \\
\text { jahat" }\end{array}$ & $\begin{array}{l}\text { sharp thorn on the } \\
\text { wicked" }\end{array}$ \\
\hline & pukul. Biar kena petir orang & "pokok itu menangis & "the tree cried for being \\
\hline & yang buat dia nangis. & $\begin{array}{ll}\text { kerana dipukul. } & \text { Biar } \\
\text { sahaja panah petir } \\
\text { terkena orang yang } \\
\text { membuat } & \text { pokok } \\
\text { menangis" } & \end{array}$ & $\begin{array}{l}\text { beaten. Let the lightning } \\
\text { bolt hit the person who } \\
\text { makes the tree cry" }\end{array}$ \\
\hline
\end{tabular}

Table 2 above shows the elements of assumptions through the opinion aspects for $A 1$ and $A 2$ for the storytelling deaf animation, namely the nipah tree. The above conversation shows a different conversation situation. A1's conversation shows a description of a nine-year-old girl giving an opinion on this folktale. Subject $A 1$ gave his opinion on the nipah tree which is often beaten by humans for craving nipah tears. In the animated series watched, the other nipah trees live happily because they know they are devoted to human beings even when they are hurt. When the greedy people arrive, then the nipah tree will be hurt because they want to take the water that comes out of the nipah tree. So subject A1 gave his opinion on the act. For example, "Pity the tree was beaten by humans. The tree has a sharp, can only the tree impose a sharp thorn on the wicked", indicating that the opinion described by subject A1 is the action he will take to do to the bad guys who damage nature. In this case, it can be described $A 1$ is very sensitive to those around who are in trouble. Furthermore, when one commits evil to another, then it is retaliated with evil. While doing good is rewarded with kindness. The month $\mathrm{A} 2$ above shows the opinion given about the animated story that was watched, namely the nipah tree. The opinion contained in the conversation above shows that A2 has a fantasy mindset that thinks that lightning will strike humans. For example, "the tree cried for being beaten. Let the lightning bolt hit the person who makes the tree cry", showing that the opinion given by $\mathrm{A} 2$ has its own uniqueness. In other words, A2 thinks that falling rain will strike humans while lightning is free to strike the earth. Thus, the statement in the form of opinion above shows that A1 and A2 have different opinions including their way of thinking, imagination and views on the animation of this folklore. 


\section{Aspects of Referencing in Folklore Animation Wood That Changes Place}

Table 3: References through Wooden Changing Places animation script

\begin{tabular}{llll}
\hline Code & Informal Malay Language & Correct Sentences & English \\
\hline A1 & "Eh, tengok tu pokok-pokok "lihat, pokok-pokok itu "see, the trees can jump \\
& boleh melompat pergitempat & boleh melompat ke somewhere else" \\
A2 lain" & tempat lain" & "haha, the tree is a pity \\
& "haha, pokok tu kesian duduk "haha, pokok itu kasihan to be alone " \\
& sorang-sorang" & $\begin{array}{l}\text { bersendirian } \\
\text { keseorangan" }\end{array}$ & \\
&
\end{tabular}

Table 3 above shows the reference elements through the opinion aspects for A1 and A2. The above conversation shows a different conversation situation. Conversation A1 shows a description of a nine-year-old girl giving an opinion on a storytelling deaf folk tale that is Wood That Moves Places. Subject A1 refers to trees shifting places. In the animated series watched, hills and other trees live happily on top of the hill. When the greedy man arrived on the hill, then the hill had to be blown up because they wanted to take the gold that was in it. So subject A1 refers to the action that takes place on the tree. For example, "see, the trees can jump somewhere else", indicates that the reference described by subject A1 is a strange way for trees. In this case, it can be described A1 is very strange looking at what happened. This is because, trees and groves cannot jump because they do not have legs and arms like humans. Furthermore, when a strange event occurred, subject A1 was unable to predict what was happening. Thus, subject A1 was amazed and eager to see what action or storyline next happened to the trees. The $A 2$ conversation above shows the reference given to the animated story being watched, which is a stick that shifts places. The reference contained in the conversation above shows a fantasy -minded A2 who assumes the tree found in the animated series has legs. For example, " haha, the tree is a pity to be alone ", indicates that the reference given by $A 2$ has is to a tree that was thrown foreign from the other trees. This is so because, A2 has a feeling of pity for the tree for living alone. Thus, the statement in the form of reference above shows that $\mathrm{A} 1$ and $\mathrm{A} 2$ have their different references or interests, including their way of thinking, imagination and views on the animation of this folklore.

\section{Palm Tree}

Table 4: Reference through Pokok Nipah animation script

\begin{tabular}{llll}
\hline Code & Informal Malay Language & Correct Sentences & English \\
\hline A1 & "apa yang lelaki tu letak "apayanglelaki ituletak & "What did the man put \\
dekat pokok tu" & $\begin{array}{l}\text { pada pokok itu" } \\
\text { "Lelaki tula jahat, buat pokok } \\
\text { tu nangis sampai luka-luka" }\end{array}$ & $\begin{array}{l}\text { "lelaki itu jahat kerana "The man is evil for } \\
\text { membuat pokok itu hurting the tree" } \\
\text { terluka" }\end{array}$ & \\
\hline
\end{tabular}

Table 4 above shows the reference elements through the opinion aspects for A1 and A2. The above conversation shows a different conversation situation. A1's conversation shows a description of a nine-year-old girl showing interest in the storytelling deaf folk tale, Pokok Nipah. Subject A1 refers to the objects placed by the youth in this animated series. In the animated series watched, the living nipah trees rejoice with their friends. When the greedy people arrived, then the nipah trees had to be cut down and digested because they wanted the nira water produced from the nipah trees. So subject A1 refers to an object placed on the frond of a nipah tree. For example, "What did the man put on the tree", indicates that the 
reference described by subject $A 1$ is an object placed on the frond of the nipah tree. This is so because, subject $A 1$ may have never seen such an object. Furthermore, subject A1 only lived in the city without knowing the objects or utensils used to extract nira water from the tree. In this case, it can be described A1 is very strange looking at an object placed on a nipah tree. Thus, subject $A 1$ was amazed and could not wait to find out the function of the object used in taking nira water. The $A 2$ conversation above shows the reference given to the animated story that was watched, namely the nipah tree. The references contained in the above conversation show A2 thinking angrily and remorsefully over the actions of the man who injured the nipah tree. For example, "The man is evil for hurting the tree ", shows that the reference given by $A 2$ is to the man who hurt the nipah tree because he was willing to hurt the nipah trees. This is so because, $A 2$ has a feeling of pity for the tree for enduring pain. Thus, the statement in the form of reference above shows that $A 1$ and $A 2$ have their different references or interests including their way of thinking, imagination and views on the animation of this folklore.

\section{Aspects of the Question in Folklore Animation Wood That Changes Place}

Table 5: Questions through wood that change place animation script

\begin{tabular}{|c|c|c|c|}
\hline Code & Informal Malay Language & Correct Sentences & English \\
\hline A1 & $\begin{array}{l}\text { "Eh, mana kawan-kawan dia } \\
\text { pergi" }\end{array}$ & $\begin{array}{l}\text { "kemanakah kawan- } \\
\text { kawan dia pergi" }\end{array}$ & $\begin{array}{l}\text { "Where did his friends } \\
\text { go?" }\end{array}$ \\
\hline A2 & $\begin{array}{l}\text { "huyo, macam mana pokok tu } \\
\text { terbang" }\end{array}$ & $\begin{array}{l}\text { "bagimana poko-pokok } \\
\text { itu terbang" }\end{array}$ & "How do the trees fly" \\
\hline
\end{tabular}

Table 5 above shows the elements of assumptions through the question aspects for $\mathrm{A} 1$ and A2. The above conversation shows a different conversation situation. Conversation A1 shows a question to a nine-year-old girl asking about the story being watched i.e. a deaf folk tale telling the story of Wood That Moves Places. Subject A1 refers to trees shifting places. In the animated series watched, hills and other trees live happily on top of the hill. When the greedy man arrived on the hill, then the hill had to be blown up because they wanted to take the gold that was in it. So subject A1 asked about trees shifting places. For example, "Where did his friends go?", indicates that the question described by subject A1 describes A1 as musykil because the kempas tree is the only one without other friends. In this case, it can be described A1 is very strange looking at what happened. This is because, A1 feels sorry to see the condition of the kempas tree and wants the kempas tree to have friends as well so that it is not alone. Furthermore, when an incident like this happens, A1 is sad because the kempas tree has no other trees. Thus, subject $A 1$ felt sad that the fund would like to know the condition of the kempas tree in the future. The $A 2$ conversation above shows the question given about the animated story being watched, which is a stick that changes places. The question contained in the conversation above shows a fantasy-minded A2 who assumes the tree found in the animated series has legs. For example, "How do the trees fly", shows that the question given by $\mathrm{A} 2$ is about trees that are thrown foreign and fly from other trees. This is so because, $A 2$ has a strange and wishful feeling for years about how the trees fly swaying. Thus, the statement in the form of reference above shows that $A 1$ and $A 2$ have their different references or interests, including their way of thinking, imagination and views on the animation of this folklore. 


\section{Palm Tree}

Table 6: Questions through palm tree animation script

\begin{tabular}{llll}
\hline Code & Informal Malay Language & Correct Sentences & English \\
\hline A1 & "Orang tu pukul pakai apa" & $\begin{array}{l}\text { "Dengan objek apakah } \\
\text { lelaki itu pukul" }\end{array}$ & $\begin{array}{l}\text { "With what object did } \\
\text { the man hit" }\end{array}$ \\
A2 & "Pokok tu boleh menari ke" & $\begin{array}{l}\text { "adakah pokok itu boleh } \\
\text { menari" }\end{array}$ & "Can the tree dance" \\
\hline
\end{tabular}

Table 6 above shows the elements of assumptions through the question aspects for $A 1$ and A2. The above conversation shows a different conversation situation. A1's conversation showed a question posed by a nine-year-old girl showing interest in the storytelling deaf folk tale of Pokok Nipah. Subject A1 questioned about the objects used to injure the nipah trees in this animated series. In the animated series watched, the living nipah trees rejoice with their friends. When the greedy people arrived, the nipah trees had to be cut down and injured because they wanted the nira water produced from the nipah trees. So subject A1 questioned the object used to take nira water from the nipah tree. For example, "With what object did the man hit", indicates that the question described by subject $A 1$ is an object used to take nira water and injure nipah trees. Furthermore, subject A1 may have never seen such an object. In addition, subject $\mathrm{A} 1$ can only be said to live in the city without knowing the objects or tools used to take nira water from the tree. In this case, it can be described A1 is very strange to see an object placed on a nipah tree and at the same time feels very sad. Thus, subject A1 did not like to see what the man did to the nipah trees by using force in taking the restricted water from the nipah trees. A2's conversation above asked about the animated story that was watched, namely the nipah tree. The questions contained in the above conversation show the minded A2 looking puzzled and questioning about the movements performed by the nipah trees. For example, "Can the tree dance ", shows that the question given by A2 is about the nipah trees that are dancing. This is so because, A2 has a puzzled look with the action of the nipah trees that is due to according to the original condition of the tree, the tree cannot dance. Furthermore, if you look at the tree, it looks stiff and only needs to be watered. So A2 is weird looking at things like that and questioning over the deeds done by the nipah trees. Thus, the statement in the form of reference above shows that $A 1$ and $A 2$ have their different references or interests including their way of thinking, imagination and views on the animation of this folklore.

\section{Summary}

Through the above animated script shows that assumptions are related to opinions, references and questions. Thus, folklore integrated into animation helps the younger generation to understand and apply the assumptions in their daily lives. From these results also displays the importance of assumptions in folklore as this will influence the animated storyline. Stories will be more interesting and assumptions can be incorporated into activities done in the classroom or at home. The results of the study are in line with the study by Noor, Eizah \& Ahmad (2019). This study also discusses civility in communication through the children's animated films, namely stereoscopic 3D animated film first Malay language in Malaysia. As well, the results of this study are very similar to the study conducted by Crosthwait (2020) conducted a study on film animation. The animation of the film studied is from the animation of the Disney-Pixar film entitled Coco. The results of this study are also in line with the study by Golding (2019). The study also argues that this animated series uses magical realism to illustrate animated capitalism in order to animate characters. In addition, 
this study was also found to be in line with the values contained in the study of Roslina (2020) said that the Malay folklore and its delivery is one of the typical Malay heritage. The results of this study are very similar to Isojärvi (2019) focuses on the elements of fatherhood introduced and the characteristics of the transition of paternal sentiment in Walt Disney's animated films: Pinocchio, Dumbo and Bambi.

\section{Conclusion}

This study shows that there are three aspects in the assumption element which include opinions, references and questions. The results of the study are expected to benefit the community especially when communicating in conversation or discussion. This is so because, communication will be impactful and meaningful through this communication strategy approach. In utterance, there will be no confusion in meaningful utterance when heard, however, communication is more focused on the message to be conveyed so that it is clearer and understood. Furthermore, the community can communicate well without offending others with the words spoken. It is hoped that future research will focus on the study of Malay folklore animation, particularly among children.

\section{Theoretical and Contextual Contribution of This Research}

Animation folklore is based on observations scientific studies which on explain the study of folklore through animation Kingfisher Stories published by Dewan Bahasa dan Pustaka (DBP). There has been no comprehensive study of animated folklore. This study applies by using discourse theory by Normaliza (2019) which emphasizes the third element which is the element of assumptions in analyzing the animated folklore of Wood That Changes Places and Palm Tree.

\section{References}

Agustin, R. (2020). Creative Content on the Digital Campaign Tokopedia "Seller Story". Jurnal Komunikasi, Jilid 36(4) 2020: 157-171. Christopher, Anita, H. S., \& Shahizah, I. H. (2019). Sang Kancil as Cultural Artefact: A Comparative Neo-Archetypal Study. Gema Online, Journal of Language Studies, Volume19(4).

Crosthwait, G. (2020). The Afterlife as Emotional Utopia in Coco. Animation: An Interdisciplinary Journal, Vol 15(2) 179-192.

Dewan Bahasa dan Pustaka. (2018). Kingfisher Stories . Animasi dan lagu. Dewan Bahasa dan Pustaka: Kuala Lumpur.

Faryna, M. K., \& Normah, M. (2017). Culture Inspiration toward Malaysian Animation Character Design. Jurnal Komunikasi, Jilid 33(1) 2017: 487-501.

Golding, D. (2019). Rocko's Magic Capitalism: Commodity Fetishim in the Magical Realism of Rocko's Modern Life. Animation: An Interdisciplinary Journal, Vol 14(1) 52-67.

Hartini, M. A., \& Normaliza, A. R. (2017). Perlambangan Kata Kerja dalam Lirik Lagu "Bebaskan" Berdasarkan Teori Relevans. Journal of Business and Social Development, Bil 5 (1): 102-111. March 2017.

Herhuth, E. (2017). Pixar and the Aesthetic Imagination. California: Universty of California Press.

Isojarvi, A. (2019). Absent Patriarchs and Persuasive Enforcers of the Future Nation: A Contectualized Reading of American Wartime Fathers in Walt Disney's Pinocchio, Dumbo and Bambi. Animation: An Interdiscipinary Journal, Vol 14(1) 37-51. 
Massila, H., \& Ima, L. E. (2020). Undercovering the Factor Influencing the Techological Adaptation of Twitter Usage Among Journalists in the Transformaing Journalism Practice. Jurnal Komunikasi, Jilid 36(4) 2020: 1-15.

Muhammad, S. I., Roslina, A. B., \& Nik, R. N. M. A. (2018). Cerita Jenaka Melayu Suatu ManifestasiWatak dan Perwatakan Positif. Jurnal Melayu, Volume 1 Issue 1 (2018): 296-329.

Mohammed, S. A. (2015). Animasi Malaysia Cetus Fenomena. Kuala Lumpur: UtusanMelayu (M) Berhad.

Muhamad, S. M., Yusmilayati, Y., \& Mohd, Y.Y. (2019). Wacana Identiti Melayu dalam Animasi Upin \& Ipin: Episod Dugaan dan Nikmat. Jurnal Melayu, Bil 18 (2) 2019.

Nik, R. N. M. A., Awang, A. A. P., \& Normaliza, A. R. (2019). The Function of University of Leiden's Malay Language Reading Materials Among Malaysian Children. Asian Social Science, Vol 15, No 4.

Noor, H. M. N., Eizah, M. H., \& Ahmad, R. A. (2019). Kesopanan dalam Komunikasi Menerusi Filem Animasi Kanak-Kanak Tempatan. Journal Komunikasi, Volume 35, No 4.

Normaliza, A. R., Nik, R. N. M. A., \& Awang, A. A. P. (2017). Dissemination of Values and Culture through the E-Folklore. TOJET: The Turkish Online Journal of Educational Technology , 16(1),32-36.

Normaliza, A. R., Awang, A. A. P., \& Nik, R. N. M. A. (2018). Integration of value and culture in Malay folklore animation. Pertanika J. Soc. Sci. \& Humanities, 26(1), 359-374.

Normaliza, A. R. (2018). Values in the Song Lyrics Among Asperger's Children: Discourse Analysis Theory. International Jurnal of Management and applied Science. 4 (12), 4447.

Normaliza, A. R. (2018). Discourse analysis theory: A new perspective in analysis. IUKL Research Journal, 7(1), 46-53.

Normaliza, A. R. (2019). Kajian wacana dan strategi komunikasi: Teori dan aplikasi.Terengganu: Penerbit Universiti Malaysia Terengganu.

Normaliza, A. R. (2019). Multimedia dalam bahasa. Serdang: Penerbit Universiti Putra Malaysia.

Normaliza, A. R., Nik, R. N. M. A., Nur, M. R., Nur, W. R., \& Siti, N. A. R. (2020). Conflict in Translation of Childen Folklore Songs. International Journal of Scientific \& Techology Research. 9 (9), 252-256.

Noraien, M., \& Normaliza, A. R. (2019). Eh!!! Media sosial. Terengganu: Penerbit Universiti Malaysia Terengganu.

Nuriyati, S., \& Fatharany, B. A. B. (2020). Myth of Baki Sea: An Observation of Banggai Matriarchal Cultural Values. Jurnal Komunikasi, Jilid 36(1) 2020: 61-75.

Roslina, A. B. (2017). Hikayat Pelanduk Jenaka: Perkembangan Kecerdasan Bodily- Kinesthetic dan Kecerdasan Bahasa Kanak-Kanak dan Remaja. Semantic Scholar, Courpus ID: 198517718.

Siti, F. M., Roslina, A. B., \& Arbai'e, S. (2019). Kisah Sang Kancil dan Memerang sebagai Penerapan Adab Kepimpinan dalam Kalangan Kanak-Kanak. Jurnal Kesidang, Volume 4 (2019): 77-89. 